\title{
Curcumin-loaded nanoparticles enhance apoptotic cell death of U2OS human osteosarcoma cells through the Akt-Bad signaling pathway
}

\author{
SHU-FEN PENG ${ }^{1 *}$, CHAO-YING LEE ${ }^{3 *}$, MANN-JEN HOUR $^{3}$, SHIH-CHANG TSAI $^{1}$, \\ DAIH-HUANG KUO ${ }^{4}$, FU-AN CHEN ${ }^{4}$, PO-CHUEN SHIEH $^{4}$ and JAI-SING YANG ${ }^{2}$ \\ Departments of ${ }^{1}$ Biological Science and Technology and ${ }^{2}$ Pharmacology, ${ }^{3}$ School of Pharmacy, China Medical University, \\ Taichung 404; ${ }^{4}$ Department of Pharmacy and Graduate Institute of Pharmaceutical Technology, \\ Tajen University, Pingtung, Taiwan, R.O.C.
}

Received August 23, 2013; Accepted October 7, 2013

DOI: 10.3892/ijo.2013.2175

\begin{abstract}
Curcumin has potential anticancer activity and has been shown to be involved in several signaling pathways including differentiation and apoptosis. Our previous study showed that water-soluble PLGA curcumin nanoparticles (Cur-NPs) triggered apoptotic cell death through regulation of the function of MDR1 and the production of reactive oxygen species (ROS) in cisplatin-resistant human oral cancer CAR cells. In this study, we investigated the anti-proliferative effects of Cur-NPs on human osteosarcoma U2OS cells. The morphology of Cur-NPs showed spherical shape by TEM analysis. The encapsulation efficiency of curcumin in Cur-NPs prepared by single emulsion was $90.5 \pm 3.0 \%$. Our results demonstrated that the curcumin fragments on the mass spectrum of Cur-NPs and the peaks of curcumin standard could be found on the Cur-NPs spectrum by ${ }^{1} \mathrm{H}-\mathrm{NMR}$ spectra analysis. Cur-NPs induced antiproliferative effects and apoptosis in U2OS cells. Compared to the untreated U2OS cells, more detectable amount of Cur-NPs was found inside the treated U2OS cells. Cur-NPs induced DNA fragmentation and apoptotic bodies in U2OS cells. Both the activity and the expression levels of caspases-3/-7 and caspase-9 were elevated in the treated U2OS cells. Cur-NPs upregulated the protein expression levels of cleaved caspase-3/ caspase-9, cytochrome $c$, Apaf-1 and Bad and downregulated the protein expression level of p-Akt in U2OS cells. These results suggest Cur-NPs are effective in enhancing apoptosis in
\end{abstract}

Correspondence to: Dr Jai-Sing Yang, Department of Pharmacology, China Medical University, No. 91 Hsueh-Shih Road, Taichung 40402, Taiwan, R.O.C.

E-mail: jaising@mail.cmu.edu.tw

*Contributed equally

Key words: curcumin nanoparticles, apoptosis, Akt, Bad, human osteosarcoma U2OS cells human osteosarcoma cells and thus could provide potential for cancer therapeutics.

\section{Introduction}

Osteosarcoma is one of the common primary malignant bone tumor diagnosed in children and teenagers $(1,2)$. Current chemotherapy regimens of osteosarcoma are based on a combination of doxorubicin, methotrexate (MTX) and cisplatin (3-6). Only 50-60\% of tumors are chemosensitive, demonstrating the dismal outcome that occurs far too often in osteosarcoma (7-9). One potential strategy to overcome known chemotherapy agents in osteosarcoma is to seek out alternative anticancer agents, particularly those appearing from natural products or traditional Chinese medicine (TCM) (10-13).

Curcumin is from the plant Curcuma longa (tumeric) and has been used in traditional Chinese medicine for thousands of years (14-18). Many pharmacological effects have been reported including anti-amyloid, anti-bacterial, anti-depressant, anti-inflammatory, anti-oxidant and anticancer properties (19-24). Curcumin has also been proven to affect multiple signaling pathways such as inhibiting cancer cell proliferation, inducing apoptosis or autophagy (25-27), blocking cell invasion and migration (28-31) and suppressing inflammatory responses (19,32-34). Phase II and III clinical trials with curcumin have advocated its use for patients with colon and pancreatic cancers (35-41). The low water solubility contributed to the poor bioavailability is the primary limiting factor for the efficacy and safety of curcumin (42-46). To improve the oral bioavailability of curcumin, we designed and developed Cur-NPs (PLGA nanoparticles loaded with curcumin) (Fig. 1A) (42). The morphology of the Cur-NPs was examined by transmission electron microscopy. The produced Cur-NPs are spherical in shape with smooth surface (Fig. 1B). Our previous study showed that the Cur-NPs caused anti-proliferation effects on cisplatin-resistant human oral cancer CAR cells, but little cytotoxicity to the normal human gingival fibroblasts cells (HGF) and normal human oral keratinocyte cells (OK) (42). The aims of this study were to characterize the properties of Cur-NPs and 
to investigate the molecular mechanisms triggered by Cur-NPs in human osteosarcoma U2OS cells.

\section{Materials and methods}

Chemicals and reagents. Cisplatin, 3-(4,5-dimethylthiazol2-yl)-2,5-diphenyltetrazolium bromide (MTT), poly(D,Llactide-co-glycolide) (PLGA, copolymer ratio 75:25, molecular weight $=66,000-92,000)$, polyvinyl alcohol (PVA, average molecular weight $=30,000-70,000)$ and curcumin were purchased from Sigma-Aldrich Corp. (St. Louis, MO, USA). Fetal bovine serum (FBS), L-glutamine, penicillin $\mathrm{G}$ and trypsin-EDTA were obtained from Life Technologies (Carlsbad, CA, USA). Caspase-3/-7 and caspase-9 activity assay kits were purchased from R\&D Systems Inc. (Minneapolis, MN, USA). The primary antibodies against caspase-3, caspase-9, Apaf-1, cytochrome $c$, AKT, p-AKT and BAD were obtained from Cell Signaling Technology Inc. (Beverly, MA, USA). All other antibodies used in this study and horseradish peroxidase (HRP)-conjugated secondary antibodies against rabbit or mouse immunoglobulin were purchased from Santa Cruz Biotechnology Inc. (Santa Cruz, CA, USA). The enhanced chemiluminescence (ECL) detection kit (Immobilon Western Chemiluminescent HRP Substrate) was obtained from Merck Millipore (Billerica, MA, USA).

Cell culture. Human osteosarcoma U2OS cell line was obtained from the Food Industry Research and Development Institute (Hsinchu, Taiwan). Cells were maintained at $37^{\circ} \mathrm{C}$ under a humidified $5 \% \mathrm{CO}_{2}$ atmosphere in $90 \%$ McCoy's $5 \mathrm{a}$ medium (Invitrogen Life Technologist, Grand Island, NY, USA) containing $2 \mathrm{mM}$ L-glutamine, $10 \%$ fetal bovine serum (Life Technologies) and 1\% penicillin-streptomycin $(100 \mathrm{U} / \mathrm{ml}$ penicillin and $100 \mu \mathrm{g} / \mathrm{ml}$ streptomycin) (Life Technologies) (47-50).

Curcumin loaded nanoparticles. Curcumin-loaded PLGA nanoparticles (Cur-NPs) were prepared by using single emulsion solvent evaporation method. Cucurmin (1 mg) and PLGA (10 mg) were dissolved in dichloromethane. The curcumin and PLGA solution ( $1 \mathrm{ml}$ ) was added to $2 \mathrm{ml}$ of $10 \%$ (w/v) PVA surfactant solution to form an oil-in-water emulsion by sonication. The emulsion was carried out by setting sonication at $55 \mathrm{~W}$ of energy output for $3 \mathrm{~min}$ over an ice bath. The formed emulsion was dispersed by dropping into the $0.5 \%$ (w/v) PVA solution and stirred for an additional $4 \mathrm{~h}$ at room temperature on a magnetic stir plate to allow evaporation of organic solvent. Nanoparticles were collected by centrifugation at 12,000 rpm for $30 \mathrm{~min}$ and washed twice with double distilled water to remove PVA and un-encapsulated curcumin. The prepared nanoparticles were collected and lyophilized (42).

Size, polydispersity index (PDI) and encapsulation efficiency. The size and the polydispersity of prepared nanoparticles (PLGA-NPs and Cur-NPs) were measured using DLS (Zetasizer Nano ZS, 3000HS, Malvern Instruments Ltd., Worcestershire, UK). To determine the encapsulation efficiency in Cur-NPs before freeze-drying, the amount of nonencapsulated curcumin was measured the absorption value of $\mathrm{OD}_{450 \mathrm{~nm}}$ by ELISA reader. The encapsulation efficiency was calculated by [(Total amount of curcumin- non-encapsulated curcumin)/Total amount of curcumin] x 100\% (51).

Transmission electron microscopy (TEM) observation. The morphology of test nanoparticles was examined by TEM (Jeol, Tokyo, Japan). A dilute suspension of nanoparticles (1/10 dilution) was prepared in double distilled water. One drop of this solution was placed on the TEM grid for $10 \mathrm{~min}$, washed twice with double distilled water and allowed to dry overnight. The images were observed and captured at an accelerating voltage of $120 \mathrm{kV}$ under a microscope (42).

NMR and mass spectra. NMR spectra were obtained on a Bruker $500 \mathrm{MHz}$ FT-NMR (model: Avance III DPX-500) spectrometer in $\mathrm{CDCl} 3$. The following abbreviations are used: s, singlet; d, doublet; $m$, multiplet. Mass spectra were measured with a Finnigan/Thermo Quest MAT 95XL instrument $(52,53)$.

Cell viability and apoptotic morphological features. The cell viability was assessed by the MTT assay. The U2OS cells were cultured in a 96-well plate at the density of $1 \times 10^{4}$ cells per well and were incubated with $0,0.25,0.5,1$ and $2 \mu \mathrm{g} / \mathrm{ml}$ of Cur-NPs for 24 and $48 \mathrm{~h}$. Then, culture medium containing $500 \mu \mathrm{g} / \mathrm{ml}$ MTT was added to each well and incubated at $37^{\circ} \mathrm{C}$ for $4 \mathrm{~h}$. After incubation, the supernatant was removed. The formed blue formazan crystals in viable U2OS cells were dissolved with isopropanol/0.04 $\mathrm{N} \mathrm{HCl}$, followed by measurement of the absorbance of each well at $570 \mathrm{~nm}$ with the ELISA reader. All experiments were performed in triplicate. The morphological examination in Cur-NPs-treated U2OS cells was determined under a phase-contrast microscope (50).

Internalization of curcumin. To track the internalization of Cur-NPs, U2OS cells $\left(1 \times 10^{6}\right)$ were seeded on 6-well plates and incubated overnight. Subsequently, cells were treated with $1 \mu \mathrm{g} / \mathrm{ml}$ of Cur-NPs for $24 \mathrm{~h}$. Finally, cells were washed with PBS twice and the internalized curcumin particles were observed under a fluorescence microscope with the filter of 488-nm excitation wavelength and 520-nm emission (27).

DNA fragmentation assay. The U2OS cells $\left(1 \times 10^{7}\right)$ were exposed to $1 \mu \mathrm{g} / \mathrm{ml}$ Cur-NPs for $48 \mathrm{~h}$. Cells were harvested, washed by PBS and then lysed in $500 \mu 1$ lysis buffer at $4^{\circ} \mathrm{C}$. The lysed cells were digested overnight with proteinase $\mathrm{K}(100 \mu \mathrm{g} / \mathrm{ml})$ at $50^{\circ} \mathrm{C}$ followed by incubation with $50 \mu \mathrm{g} / \mathrm{ml}$ RNase A at $37^{\circ} \mathrm{C}$ for $1 \mathrm{~h}$. DNA fragments were extracted twice with phenol/chloroform/ isopropanol $(24: 25: 1 ; \mathrm{v} / \mathrm{v} / \mathrm{v})$ and precipitated with $50 \%$ isopropanol with glycogen $(20 \mu \mathrm{g} / \mathrm{ml})$ before being re-suspended in $100 \mu 1$ Tris-EDTA (TE) buffer (Amresco Inc., Solon, OH, USA). Samples were electrophoresed on $1.8 \%$ (w/v) agarose gel (SigmaAldrich Corp.) in 0.5X TBE buffer (Amresco Inc.) and DNA was stained with $1 \mu \mathrm{g} / \mathrm{ml}$ ethidium bromide (Life Technologies). The gel was observed and photographed under a UV lamp $(54,55)$.

Western blot analysis. The U2OS cells $\left(1 \times 10^{7}\right)$ were treated with $0,0.5,1$ and $2 \mu \mathrm{g} / \mathrm{ml}$ of Cur-NPs for 12 or $48 \mathrm{~h}$. Cells were then harvested, lysed and the total proteins were collected by SDS sample buffer. Approximately $50 \mu \mathrm{g}$ of proteins from each treatment were resolved on $10 \%$ SDS-polyacrylamide gel electrophoresis (PAGE) and electro-transferred to the 
A<smiles>CC(C)COC(=O)CC(C)C(=O)O</smiles><smiles>COc1cc(C/C=C(\O)C/C=C(\O)C/C=C/C2CCCCC2)ccc1O</smiles>
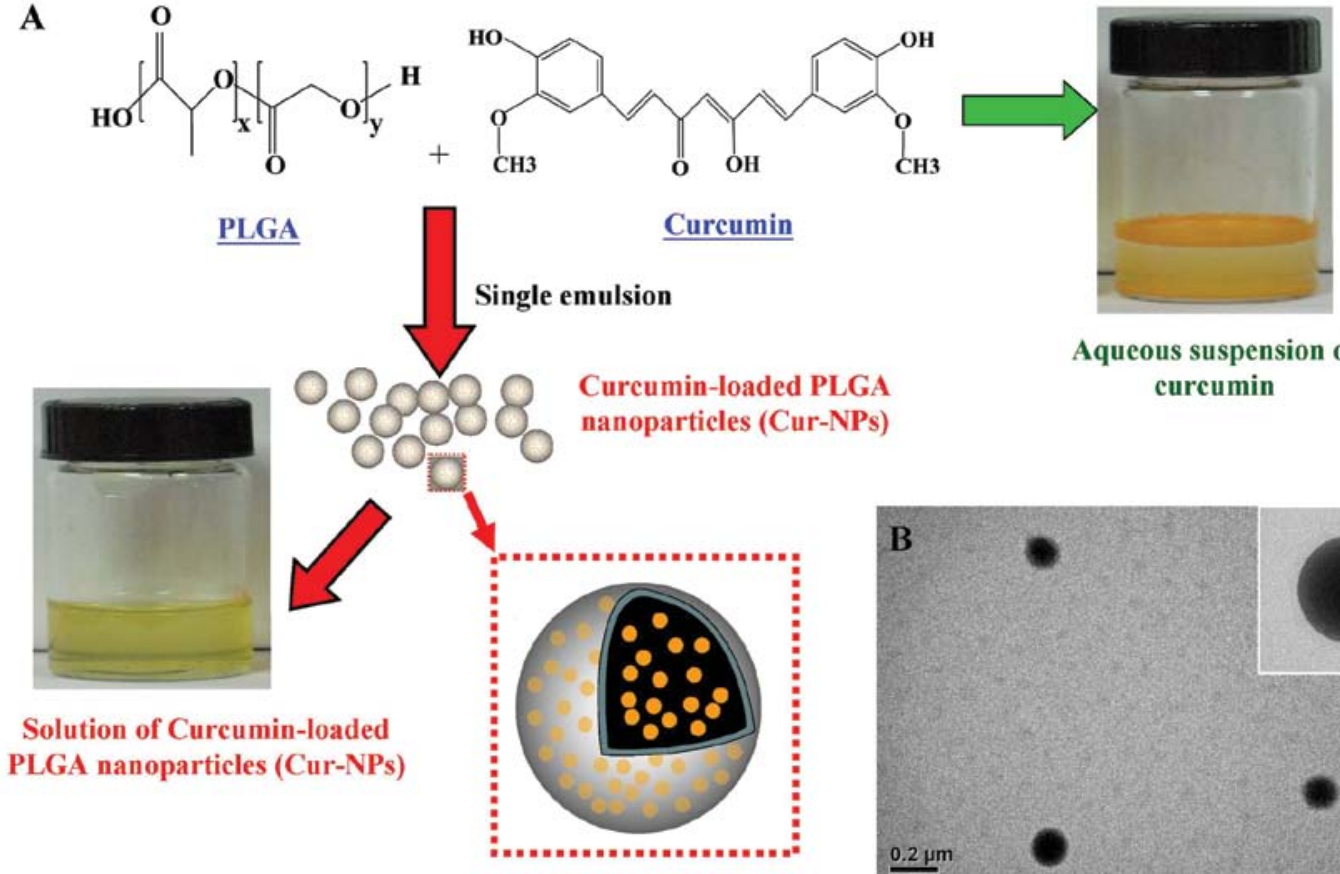

Aqueous suspension of curcumin

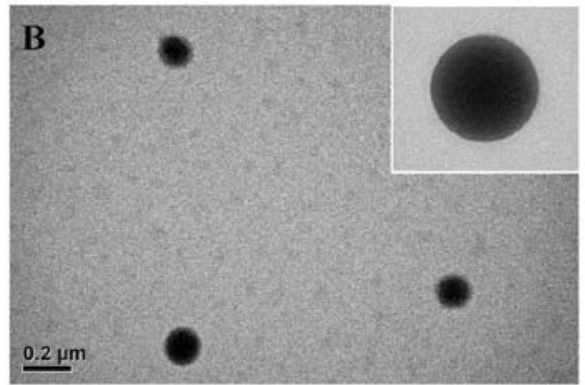

Figure 1. (A) The schematic diagram of Cur-NPs preparation. The curcumin was encapsulated in the PLGA by single emulsion. (B) Morphology observation of Cur-NPs by TEM. The Cur-NPs show spherical shape.

Immobilon-P Transfer Membrane (Merck Millipore). The transferred membranes were blocked with $5 \%$ non-fat dry milk in $20 \mathrm{mM}$ Tris-buffered saline/0.05\% Tween-20 for $1 \mathrm{~h}$ at room temperature followed by incubation with appropriate primary antibodies at $4^{\circ} \mathrm{C}$ overnight. At the end of incubation, membranes were washed with Tris-buffered saline/Tween-20 and incubated with secondary antibodies conjugated with HRP. The blots were developed by the chemiluminescence kit and then exposed to X-ray film. Each membrane was stripped and reprobed with anti- $\beta$-actin antibody (Sigma-Aldrich Corp.) to ensure equal protein loading during the experiments $(47,56,57)$.

Assays for caspase-3/-7 and caspase-9 activities. The U2OS cells $\left(1 \times 10^{7}\right)$ were exposed to $1 \mu \mathrm{g} / \mathrm{ml}$ of Cur-NPs for 0,12 , 24, 36 and $48 \mathrm{~h}$. Subsequently, cells were harvested, and cell lysates were assessed in accordance with the manufacturer's instructions provided in the caspase-3/-7 and caspase- 9 colorimetric assay kits (R\&D System Inc.). Cell lysate containing $50 \mu \mathrm{g}$ proteins were then incubated for $1 \mathrm{~h}$ at $37^{\circ} \mathrm{C}$ with specific caspase-3/-7 substrate (DEVD-pNA) or caspase-9 substrate (LEHD-pNA) and determined by measuring $\mathrm{OD}_{405}$ of the released pNA (58-60).

Statistical analysis. All the statistical results are performed as the mean \pm standard error of the mean (SEM) for the indicated numbers of independent experiments. Statistical analyses of data were done using one-way ANOVA followed by Student's $\mathrm{t}$-test and the levels of $\mathrm{P}<0.001$ was considered significant between the treated and untreated group (61).

\section{Results}

Characterization of Cur-NPs. In order to improve the application of curcumin, curcumin was encapsulated by PLGA
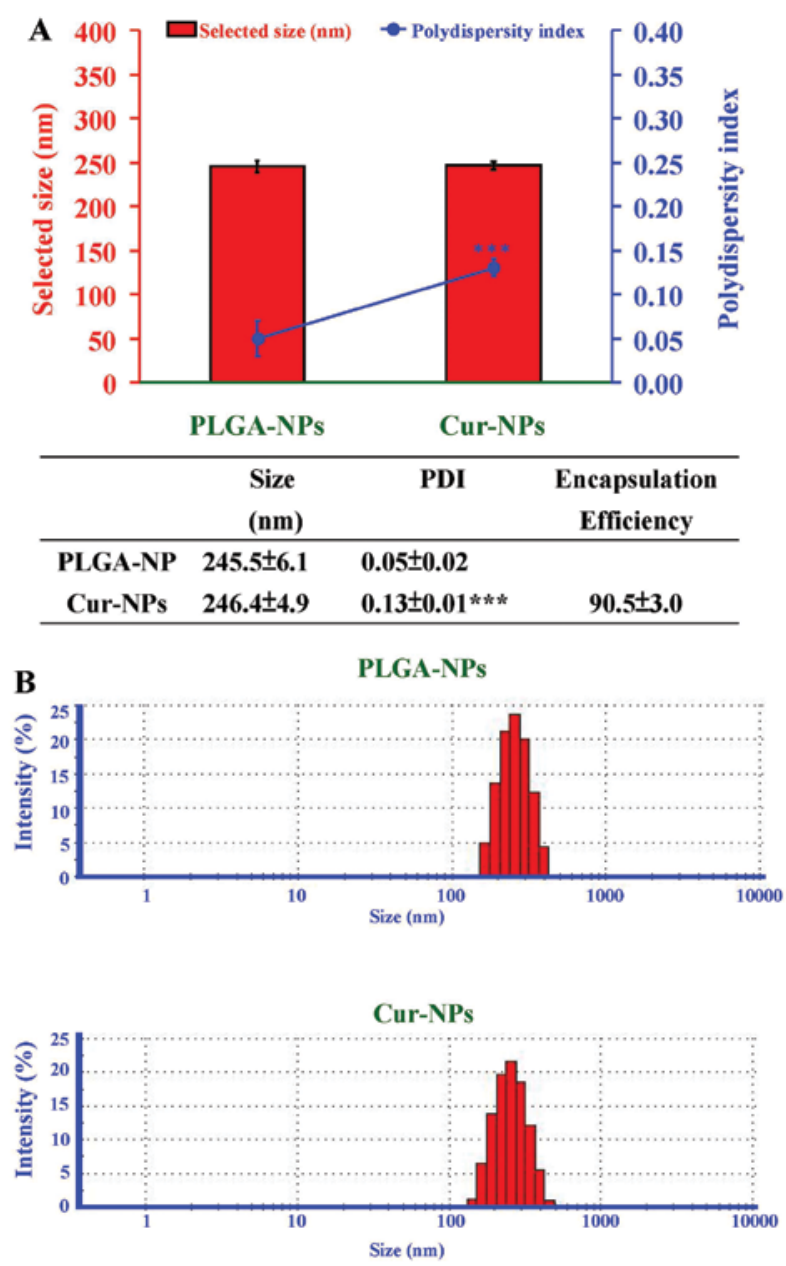

Figure 2. (A) The size and polydispersity index of PLGA-NPs and Cur-NPs measured by DLS. The encapsulation efficiency of both nanoparticles was determined by measuring the value of $\mathrm{OD}_{450 \mathrm{~nm}}$. (B) The size distribution of PLGA-NPs and Cur-NPs was measured by DLS. 

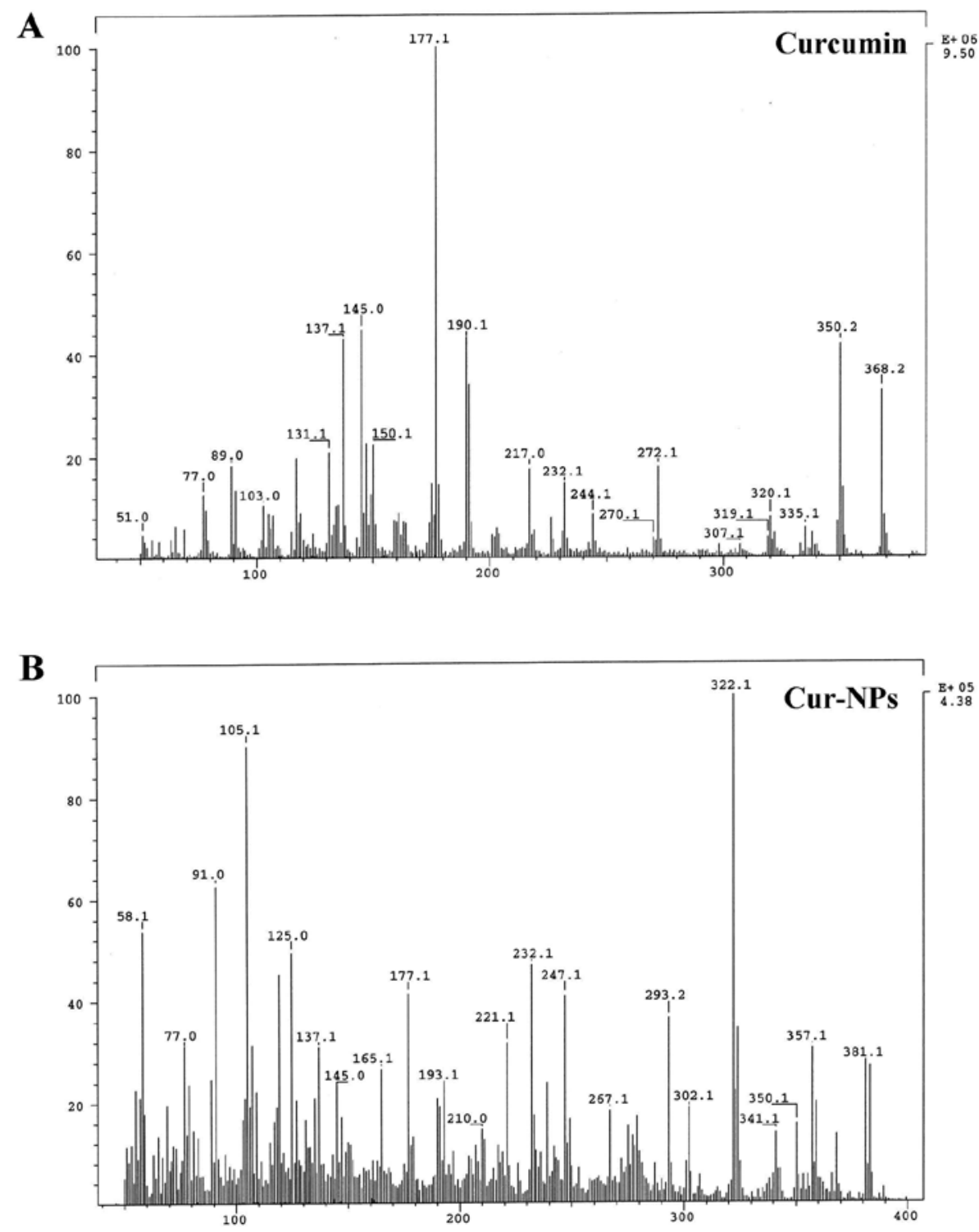

Figure 3. Mass spectra of curcumin (A) and Cur-NPs (B). The mass spectra of curcumin and Cur-NPs were determined as described in Materials and methods.

to form curcumin-loaded PLGA nanoparticles (Cur-NPs) by single emulsion method (Fig. 1A). The nanoparticle form of curcumin exhibited good water-solubility and formed a transparent solution while dissolving in water. TEM was used to examine the morphology of the Cur-NPs. As shown, the Cur-NPs showed spherical shape (Fig. 1B). The size distribution of Cur-NPs in aqueous solution was measured by DLS. As shown in Fig. 2A, the size of Cur-NPs is $\sim 250 \mathrm{~nm}$, similar to the curcumin-empty PLGA-NPs. Both nanoparticles showed small polydispersity index (PDI) (Fig. 2A), indicating their homogeneous size distribution (Fig. 2B). The encapsulation efficiency of curcumin in Cur-NPs prepared by single emulsion was $90.5 \pm 3.0 \%$ (Fig. $2 \mathrm{~A}$ ).

In order to confirm that curcumin was unaffected after nano-technologization, mass (MS) spectroscopy of curcumin and Cur-NPs were performed and we found the curcumin fragments on MS spectrum of Cur-NPs (Fig. 3). Furthermore, the proton nuclear magnetic resonance ( $\left.{ }^{1} \mathrm{H}-\mathrm{NMR}\right)$ spectroscopy was used to obtain the ${ }^{1} \mathrm{H}-\mathrm{NMR}$ spectra of PLGA-NPs [poly(lactic-co-glycolic acid) nanoparticles], curcumin standard and Cur-NPs (Fig. 4). Comparing Fig. 4A and B, all the peaks of curcumin standard (Fig. 4A) could be found on the Cur-NPs spectrum (Fig. 4B) with identical chemical shifts and integration. Besides the peaks of curcumin, there were some other peaks, $\delta 1.58-1.62(354 \mathrm{H}, \mathrm{m}), 4.66-4.93(58 \mathrm{H}, \mathrm{m})$ and 5.17-5.27 $(89 \mathrm{H}, \mathrm{m})$, on the Cur-NPs spectrum. The chemical shifts and integration ratio ( 4:0.6:1) of these additional peaks are identical with that of PLGA NPs, $\delta 1.58-1.62(4 \mathrm{H}, \mathrm{m})$, 4.63-4.93 $(0.6 \mathrm{H}, \mathrm{m})$ and 5.17-5.27 $(1 \mathrm{H}, \mathrm{m})$. From the careful inspections of spectral data described above, curcumin was constant and unaffected by nano-technologization.

Cur-NPs reduce the viability of human osteosarcoma U2OS cells. The U2OS cells were treated with Cur-NPs $(0,0.25$, $0.5,1$ and $2 \mu \mathrm{g} / \mathrm{ml}$ ) for 24 and $48 \mathrm{~h}$. The cells were collected and the cell viability was determined using MTT assay. Our results showed that the concentrations of $0.25,0.5,1$ and $2 \mu \mathrm{g} /$ ml Cur-NPs significantly decreased cell viability in U2OS 
A

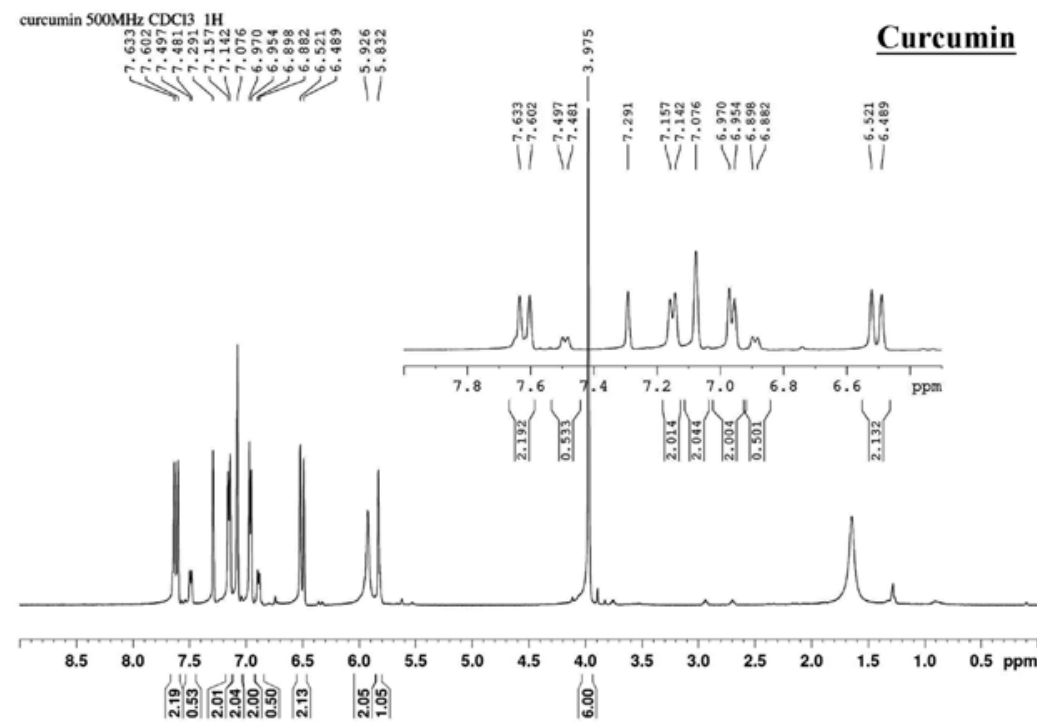

B

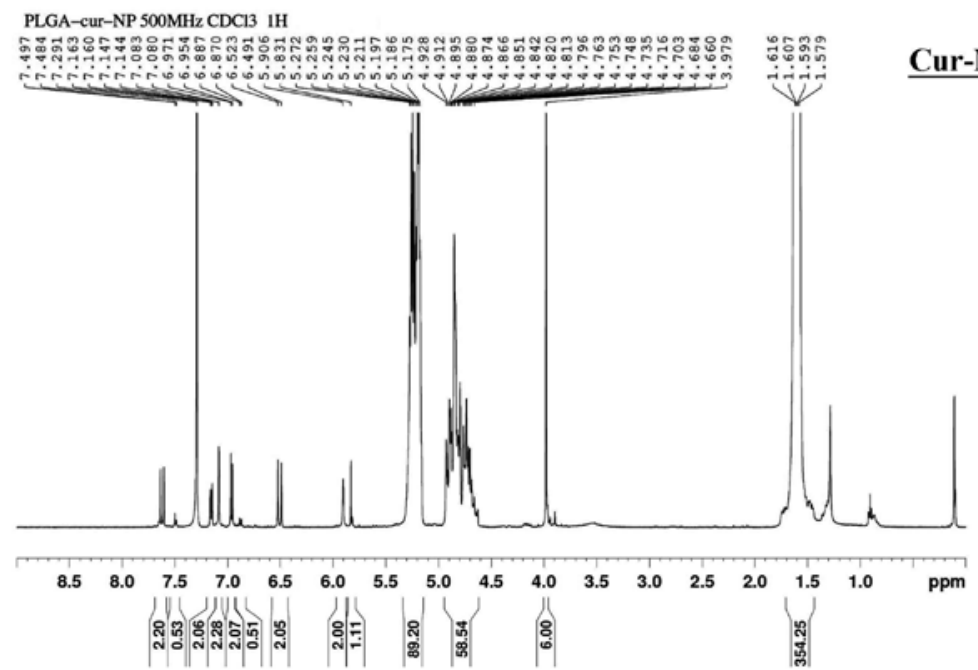

Figure 4. ${ }^{1} \mathrm{H}-\mathrm{NMR}$ spectra of curcumin (A) and Cur-NPs (B). The ${ }^{1} \mathrm{H}-\mathrm{NMR}$ spectra of curcumin and Cur-NPs were determined as described in Materials and methods.

cells concentration- and time-dependently (Fig. 5A). Cellular uptake of Cur-NPs was visualized by green fluorescence of curcumin using fluorescence microscopy (Fig. 5B). Intensified fluorescence was detected in the cytoplasm and nucleus of cells treated with Cur-NPs, suggesting the amount of curcumin internalized into the cells. Our results demonstrated that Cur-NPs display the anti-human osteosarcoma U2OS cells in vitro.

Cur-NPs induce apoptosis in human osteosarcoma U2OS cells. After treatment with $0.5,1$ and $2 \mu \mathrm{g} / \mathrm{ml}$ of Cur-NPs for $48 \mathrm{~h}$, Fig. 6A revealed apoptotic bodies in Cur-NPs-treated U2OS cells and this effect is concentration-dependent. Further results are demonstrated in Fig. 6B, which indicated that Cur-NPs induced DNA fragmentation in Cur-NPs-treated U2OS cells.

Cur-NPs trigger mitochondria-dependent apoptotic cell death in U2OS cells. To examine whether Cur-NPs induces apoptosis in U2OS cells, cells were treated with $1 \mu \mathrm{g} / \mathrm{ml}$ of Cur-NPs for
$0,12,24,36$ and $48 \mathrm{~h}$ before subjected to caspase-3/-7 and caspase-9 activities. Cur-NPs stimulated caspase-9 (Fig. 7A) and caspase-3/-7 (Fig. 7B) activities in Cur-NPs-treated U2OS cells and this effect is time-dependent. Based on these findings, we provide evidence regarding the intrinsic caspase contributing to Cur-NPs-induced apoptosis in U2OS cells.

Mitochondria-dependent and Akt-Bad signaling pathways were involved in Cur-NPs-induced apoptosis in U2OS cell apoptosis. We examined the effects of Cur-NPs on mitochondria-dependent and Akt-Bad signaling pathways in U2OS cells. The immunoblotting results showed that the protein level of p-Akt was decreased in Cur-NPs-treated U2OS cells (Fig. 8A). In contrast, the protein levels of cleaved caspase-3, cleaved caspase-9, cytochrome $c$, Apaf-1 and Bad were increased in Cur-NPs-treated U2OS cells (Fig. 8B). In conclusion, our data expand the current understanding of Cur-NPs treatment in U2OS cells on causing cell death through the mitochondrial-dependent caspase cascade and the Akt-Bad signaling in vitro. 

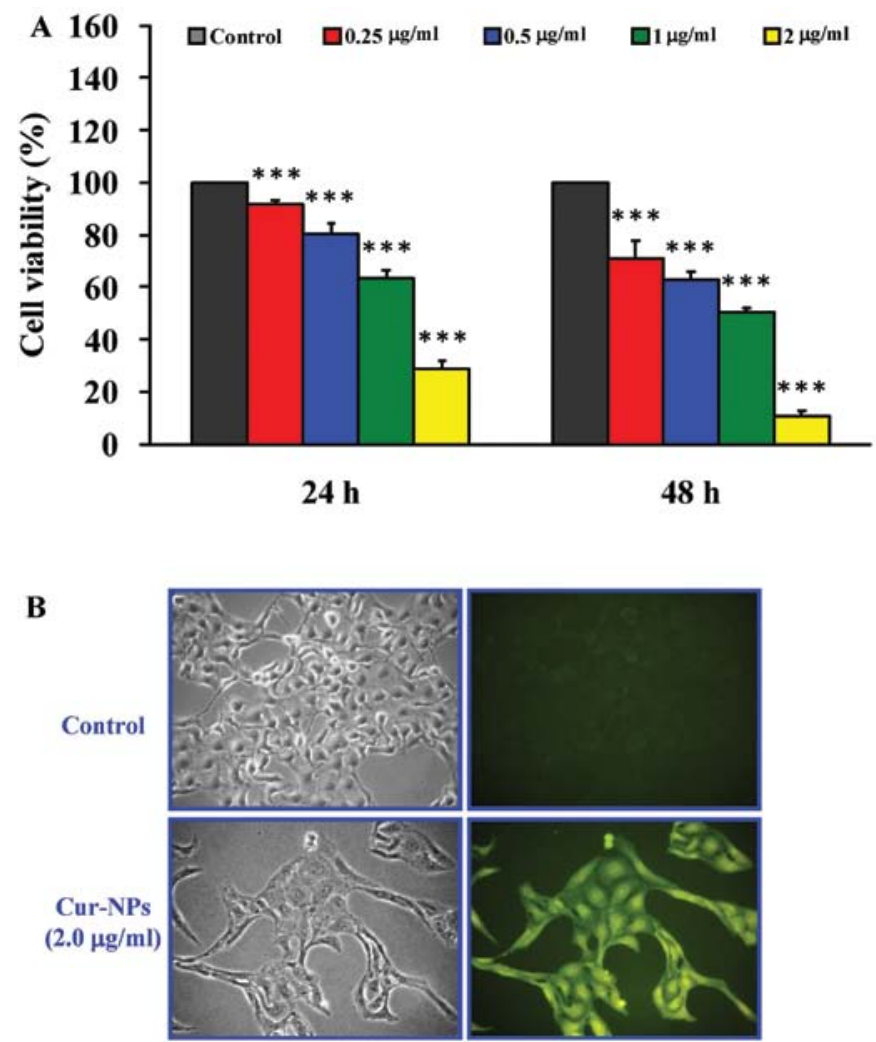

Figure 5. Effects of Cur-NPs on cell viability and cellular uptake in human osteosarcoma U2OS cells. (A) Effects of Cur-NPs on cell viability in U2OS cells for 24 and $48 \mathrm{~h}$. Cells were incubated in the absence or presence of $0,0.25,0.5,1$ and $2 \mu \mathrm{g} / \mathrm{ml}$ of Cur-NPs for 24 and $48 \mathrm{~h}$. Cell viability on Cur-NPs-treated cells were determined using the MTT assay as described in Materials and methods. Data are presented as the mean \pm SEM in triplicate by comparing between the treated and untreated control cells. ${ }^{* * *} \mathrm{P}<0.001$ compared with the control value. (B) To track the internalization of Cur-NPs, U2OS cell were incubated without (control) or with Cur-NPs containing $2 \mu \mathrm{g} /$ $\mathrm{ml}$ for $24 \mathrm{~h}$. The internalized curcumin was observed under a fluorescence microscope with the filter of 488-nm excitation wavelength and 520-nm emission.

\section{Discussion}

The study published by Yin et al demonstrated that Cur-NPs are effective in inhibiting the growth of human lung cancer and exhibited little toxicity to normal tissues in an established A549 xenograft mouse model $(42,62)$. Our previous study also showed that the Cur-NPs used in our study caused anti-proliferation effects on CAR cells in a dose- and time-dependent manner but little cytotoxicity to the normal human gingival fibroblasts cells (HGF) and normal human oral keratinocyte cells (OK) (29). This is the first study to investigate the anti-human osteosarcoma effects of Cur-NPs on human osteosarcoma U2OS cells. Our results showed that Cur-NPs inhibited U2OS cell proliferation (Fig. 5) and induced apoptotic cell death (Fig. 6) in a concentration- and time-dependent manner. The results in Fig. 7 show Cur-NPs enhanced cell apoptosis through the activation of caspase-9 and caspase-3/-7 in U2OS cells. Our results suggested that Cur-NPs-induced apoptosis might be through the mitochondria-dependent signaling pathway, which has a connection with the activation of caspase- 9 and -3 .

Previous research has shown that mitochondrial-mediated apoptosis is regulated by the Bcl-2 family proteins (63-65).

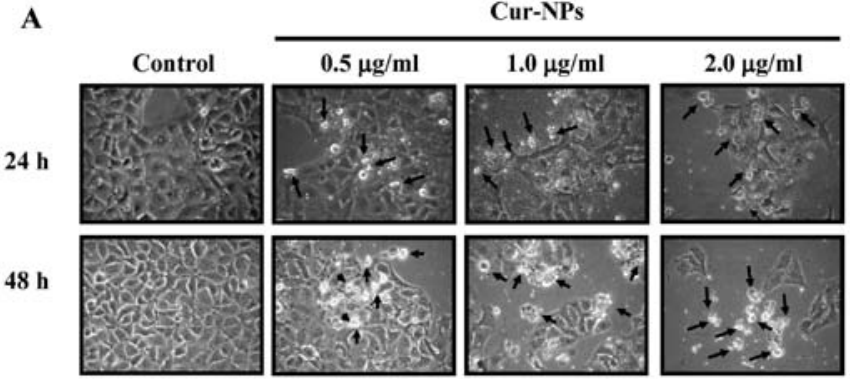

B

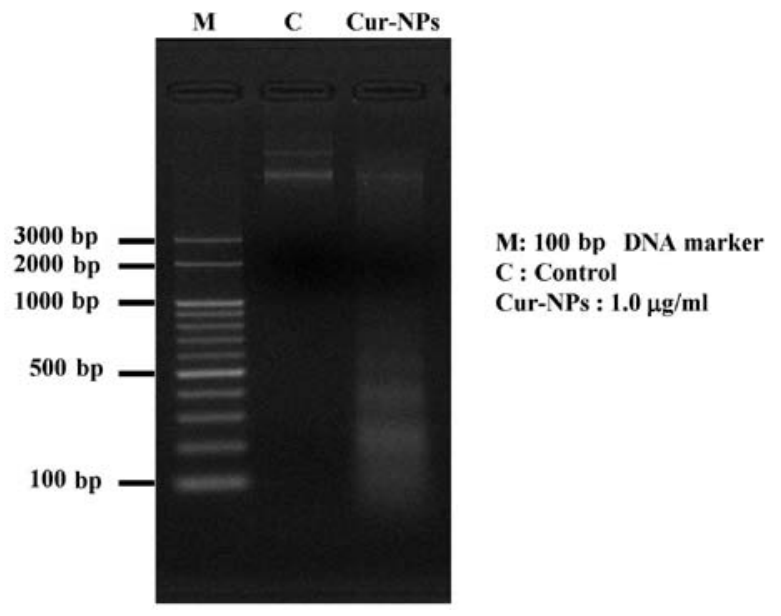

Figure 6. Effects of Cur-NPs on cell morphology and DNA fragmentation in human osteosarcoma U2OS cells. (A) For morphological examination, U2OS cells were treated with $0,0.5,1$ and $2 \mu \mathrm{g} / \mathrm{ml}$ of Cur-NPs for $48 \mathrm{~h}$. The morphological examination was determined under a phase-contrast microscope. (B) For DNA fragmentation assay, U2OS cells were treated with 0 and $1 \mu \mathrm{g} /$ $\mathrm{ml}$ of Cur-NPs for $48 \mathrm{~h}$. Cells were harvested and then were measured for apoptosis by DNA gel electrophoresis as described in Materials and methods.
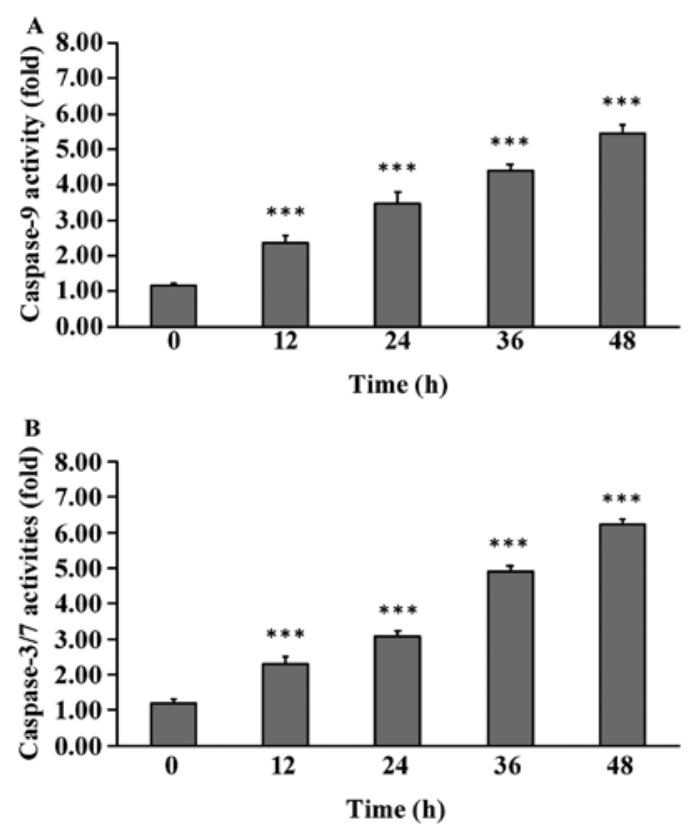

Figure 7. Effects of caspase-9 (A) and caspase-3/-7 (B) activities on Cur-NPstreated human osteosarcoma U2OS cells. Cells were treated with $1 \mu \mathrm{g} / \mathrm{ml}$ of Cur-NPs and then incubated for $24 \mathrm{~h}$. The whole-cell lysates were subjected to caspase activity assay as described in Materials and methods. Each result is shown as the mean \pm SEM in triplicate by comparing between the treated and untreated control cells. ${ }^{* * *} \mathrm{P}<0.001$ compared with the control value. 
A

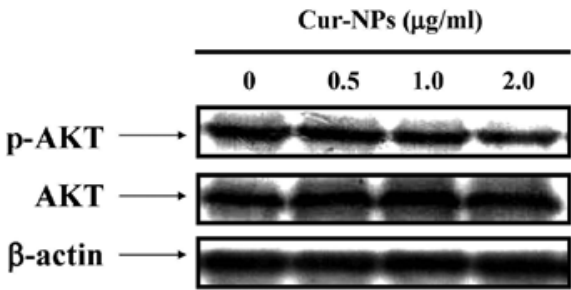

B

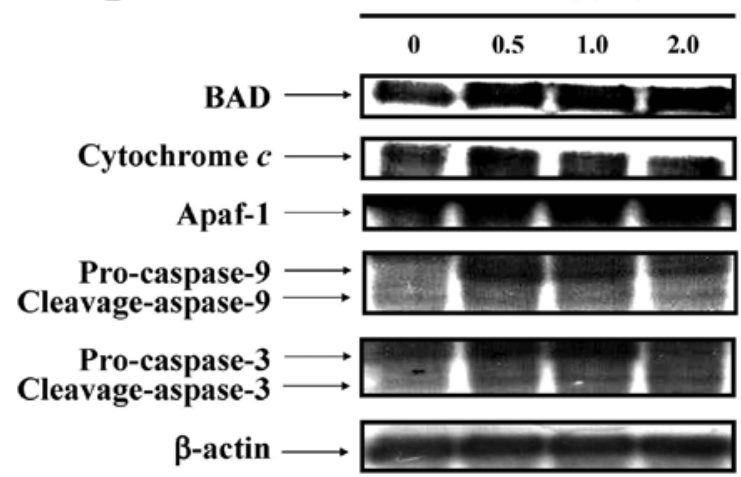

Figure 8. Effects of Cur-NPs caused protein level change on mitochondriadependent apoptosis and AKT-BAD signaling in human osteosarcoma U2OS cells. The U2OS cells were treated with $0,0.5,1$ and $2 \mu \mathrm{g} / \mathrm{ml}$ of Cur-NPs for 0,12 and $48 \mathrm{~h}$ then subjected to western blotting. The western blotting of (A) p-AKT, AKT and (B) BAD, cytochrome $c$, Apaf-1, caspase-3, caspase-9 protein levels in $\mathrm{U} 2 \mathrm{OS}$ cells. The $\beta$-actin was detected for equivalent protein loading.

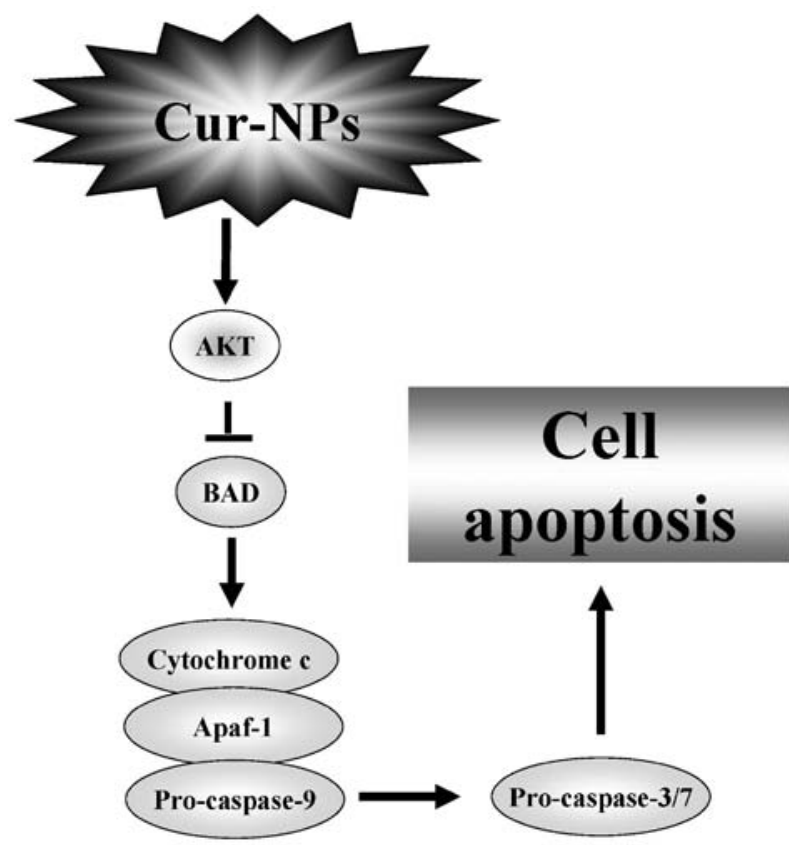

Figure 9. Schematic diagram of Cur-NPs regulating the apoptotic signaling pathway in human osteosarcoma U2OS cells.

The Bcl-2 family includes pro-apoptotic proteins (Bax and Bad) and anti-apoptotic proteins (Bcl-2 and Bcl-xL) (66-70). The ratio of pro-apoptotic and anti-apoptotic proteins is thought to determine, at least in part, the susceptibility of cells to a death signal $(68,69,71)$. Previous studies have shown that the apoptotic stimuli can de-phosphorylate Bad and release
Bad from the 14-3-3 protein (72-75). Thus, Bad will compete with Bcl-2/Bcl-xL in binding to Bax (76-79). Previously, it was shown that functional Akt phosphorylated Bad at Ser136 to promote the stabilization of the mitochondrial membrane system and cell survival $(78,80)$. Our results demonstrated that the protein level of p-AKT was decreased (Fig. 8A), while the protein levels of cleaved caspase-3, cleaved caspase-9, cytochrome $c$, Apaf-1 and BAD were increased in Cur-NPstreated U2OS cells (Fig. 8B). The results suggest that Cur-NPs enhance apoptotic cell death of human osteosarcoma U2OS cells through the Akt-Bad signaling pathway.

In conclusion, Cur-NPs induce cell apoptosis in human osteosarcoma U2OS cells. The findings suggest that the major pharmacologic action of Cur-NPs is to trigger apoptotic cell death through activation of caspase- 9 and caspase-3/-7 connected to mitochondria-dependent and Akt-Bad signaling pathway in U2OS cells (Fig. 9). Cur-NPs could be one of the potential compounds to be developed as a novel medicine against human osteosarcoma.

\section{Acknowledgements}

This study was supported by research grant from the China Medical University (CMU101-N2-07) to Dr Shu-Fen Peng.

\section{References}

1. Ferrari S, Palmerini E, Fabbri N, et al: Osteosarcoma of the pelvis: a monoinstitutional experience in patients younger than 41 years. Tumori 98: 702-708, 2012.

2. Anninga JK, Picci P, Fiocco M, et al: Osteosarcoma of the hands and feet: a distinct clinico-pathological subgroup. Virchows Arch 462: 109-120, 2013.

3. Colomina J, Peiro A, Trullols L and Garcia I: Telangiectatic osteosarcoma. J Orthop Surg 21: 96-99, 2013.

4. Ebb D, Meyers P, Grier H, et al: Phase II trial of trastuzumab in combination with cytotoxic chemotherapy for treatment of metastatic osteosarcoma with human epidermal growth factor receptor 2 overexpression: a report from the Children's Oncology Group. J Clin Oncol 30: 2545-2551, 2012.

5. Ritter J and Bielack SS: Osteosarcoma. Ann Oncol 21 (Suppl 7): vii320-vii325, 2010.

6. Seki K, Yoshikawa H, Shiiki K, Hamada Y, Akamatsu N and Tasaka K: Cisplatin (CDDP) specifically induces apoptosis via sequential activation of caspase- $8,-3$ and -6 in osteosarcoma. Cancer Chemother Pharmacol 45: 199-206, 2000.

7. Warzecha J, Gottig S, Chow KU, et al: Inhibition of osteosarcoma cell proliferation by the Hedgehog-inhibitor cyclopamine. J Chemother 19: 554-561, 2007.

8. Valteau-Couanet D and Minard V: Poor prognosis childhood cancers. Rev Prat 57: 1087-1091, 2007 (In French).

9. Rouesse $\mathrm{J}$ and Le Chevalier J: Combination of chemotherapy and surgery in pulmonary metastases of tumors considered not very chemosensitive. Chirurgie 111: 538-541, 1985 (In French).

10. Wang Y, Fu Q and Zhao W: Tetramethylpyrazine inhibits osteosarcoma cell proliferation via downregulation of $\mathrm{NF}-\kappa \mathrm{B}$ in vitro and in vivo. Mol Med Rep 8: 984-988 2013.

11. Shi QW, Li SG, Li J and Ling CQ: Anti-tumor effects of triptolide on osteosarcoma cells in vitro and in vivo: an experimental research. Zhongguo Zhong Xi Yi Jie He Za Zhi 33: 659-663, 2013 (In Chinese).

12. Yang JY, Cheng FW, Wong KC, et al: Initial presentation and management of osteosarcoma, and its impact on disease outcome. Hong Kong Med J 15: 434-439, 2009.

13. Zhang YK, Zhang XH, Li JM, Sun de S, Yang Q and Diao DM: A proteomic study on a human osteosarcoma cell line Saos-2 treated with diallyl trisulfide. Anticancer Drugs 20: 702-712, 2009.

14. Yin H, Guo R, Xu Y, et al: Synergistic antitumor efficiency of docetaxel and curcumin against lung cancer. Acta Biochim Biophys Sin 44: 147-153, 2012. 
15. Tang $\mathrm{N}$, Zhang $\mathrm{J}$ and $\mathrm{Du} \mathrm{Y}$ : Curcumin promoted the apoptosis of cisplain-resistant human lung carcinoma cells A549/DDP through down-regulating miR-186* . Zhongguo Fei Ai Za Zhi 13: 301-306, 2010 (In Chinese).

16. Chen ZQ and Mo ZN: Curcumin in the treatment of prostatic diseases. Zhonghua Nan Ke Xue 14: 67-70, 2008 (In Chinese).

17. Sagar SM, Yance D and Wong RK: Natural health products that inhibit angiogenesis: a potential source for investigational new agents to treat cancer - Part 2. Curr Oncol 13: 99-107, 2006.

18. Shishodia S, Sethi G and Aggarwal BB: Curcumin: getting back to the roots. Ann NY Acad Sci 1056: 206-217, 2005.

19. Sareen R, Jain N and Pandit V: Curcumin: a boon to colonic diseases. Curr Drug Targets 14: 1210-1218, 2013.

20. Patra D, Ahmadieh D and Aridi R: Study on interaction of bile salts with curcumin and curcumin embedded in dipalmitoylsn-glycero-3-phosphocholine liposome. Colloids Surf B Biointerfaces 110: 296-304, 2013.

21. Mathew A, Fukuda T, Nagaoka Y, et al: Curcumin loaded-PLGA nanoparticles conjugated with Tet-1 peptide for potential use in Alzheimer's disease. PLoS One 7: e32616, 2012.

22. Bolognesi ML, Bartolini M, Tarozzi A, et al: Multitargeted drugs discovery: balancing anti-amyloid and anticholinesterase capacity in a single chemical entity. Bioorg Med Chem Lett 21: $2655-2658,2011$

23. Khan S and Heikkila JJ: Curcumin-induced inhibition of proteasomal activity, enhanced HSP accumulation and the acquisition of thermotolerance in Xenopus laevis A6 cells. Comp Biochem Physiol A Mol Integr Physiol 158: 566-576, 2011.

24. Zhou H, Beevers CS and Huang S: The targets of curcumin. Curr Drug Targets 12: 332-347, 2011.

25. Khan MA, Gahlot S and Majumdar S: Oxidative stress induced by curcumin promotes the death of cutaneous T-cell lymphoma (HuT-78) by disrupting the function of several molecular targets. Mol Cancer Ther 11: 1873-1883, 2012.

26. Han J, Pan XY, Xu Y, et al: Curcumin induces autophagy to protect vascular endothelial cell survival from oxidative stress damage. Autophagy 8: 812-825, 2012

27. O'Sullivan-Coyne G, O'Sullivan GC, O'Donovan TR, Piwocka K and McKenna SL: Curcumin induces apoptosis-independent death in oesophageal cancer cells. Br J Cancer 101: 1585-1595, 2009.

28. Chen HW, Lee JY, Huang JY, et al: Curcumin inhibits lung cancer cell invasion and metastasis through the tumor suppressor HLJ1. Cancer Res 68: 7428-7438, 2008.

29. Wang WX, Sun SZ, Guo XL and Song Y: Effect of curcumin on invasion and migration of tongue squamous cell carcinoma cell line Tca8113. Zhonghua Kou Qiang Yi Xue Za Zhi 43: 101-104, 2008.

30. Lin CW, Hou WC, Shen SC, et al: Quercetin inhibition of tumor invasion via suppressing PKC delta/ERK/AP-1-dependent matrix metalloproteinase- 9 activation in breast carcinoma cells. Carcinogenesis 29: 1807-1815, 2008.

31. Philip S, Bulbule A and Kundu GC: Matrix metalloproteinase-2: mechanism and regulation of NF-kappaB-mediated activation and its role in cell motility and ECM-invasion. Glycoconj J 21 : 429-441, 2004

32. Cho YJ, Yi CO, Jeon BT, et al: Curcumin attenuates radiationinduced inflammation and fibrosis in rat lungs. Korean J Physiol Pharmacol 17: 267-274, 2013

33. Bowden RG, J JM, Deike E, et al: The use of an anti-inflammatory supplement in patients with chronic kidney disease. J Complement Integr Med 10: 1-10, 2013.

34. Asher GN and Spelman K: Clinical utility of curcumin extract. Altern Ther Health Med 19: 20-22, 2013.

35. Shehzad A, Wahid F and Lee YS: Curcumin in cancer chemoprevention: molecular targets, pharmacokinetics, bioavailability, and clinical trials. Arch Pharm 343: 489-499, 2010.

36. Kossler S, Nofziger C, Jakab M, Dossena S and Paulmichl M: Curcumin affects cell survival and cell volume regulation in human renal and intestinal cells. Toxicology 292: 123-135, 2012

37. Ji JL, Huang XF and Zhu HL: Curcumin and its formulations: potential anti-cancer agents. Anticancer Agents Med Chem 12: 210-218, 2012

38. Gulcubuk A, Altunatmaz K, Sonmez K, et al: Effects of curcumin on tumour necrosis factor-alpha and interleukin-6 in the late phase of experimental acute pancreatitis. J Vet Med A Physiol Pathol Clin Med 53: 49-54, 2006.

39. Greenwald P, Milner JA, Anderson DE and McDonald SS Micronutrients in cancer chemoprevention. Cancer Metastasis Rev 21: 217-230, 2002.
40. Kelloff GJ, Boone CW, Crowell JA, et al: New agents for cancer chemoprevention. J Cell Biochem (Suppl) 26: 1-28, 1996.

41. Kelloff GJ, Boone CW, Crowell JA, Steele VE, Lubet R and Sigman CC: Chemopreventive drug development: perspectives and progress. Cancer Epidemiol Biomarkers Prev 3: 85-98, 1994

42. Chang PY, Peng SF, Lee CY, et al: Curcumin-loaded nanoparticles induce apoptotic cell death through regulation of the function of MDR1 and reactive oxygen species in cisplatin-resistant CAR human oral cancer cells. Int J Oncol 43: 1141-1150, 2013.

43. Manju S and Sreenivasan K: Gold nanoparticles generated and stabilized by water soluble curcumin-polymer conjugate: blood compatibility evaluation and targeted drug delivery onto cancer cells. J Colloid Interface Sci 368: 144-151, 2012.

44. Bhawana, Basniwal RK, Buttar HS, Jain VK and Jain N: Curcumin nanoparticles: preparation, characterization, and antimicrobial study. J Agric Food Chem 59: 2056-2061, 2011.

45. Bansal SS, Vadhanam MV and Gupta RC: Development and in vitro-in vivo evaluation of polymeric implants for continuous systemic delivery of curcumin. Pharm Res 28: 1121-1130, 2011.

46. Mukerjee A and Vishwanatha JK: Formulation, characterization and evaluation of curcumin-loaded PLGA nanospheres for cancer therapy. Anticancer Res 29: 3867-3875, 2009.

47. Chen HJ, Lin CM, Lee CY, et al: Kaempferol suppresses cell metastasis via inhibition of the ERK-p38-JNK and AP-1 signaling pathways in U-2 OS human osteosarcoma cells. Oncol Rep 30: 925-932, 2013.

48. Chen KT,Hour MJ, Tsai SC, et al: The novel synthesized 6-fluoro(3-fluorophenyl)-4-(3-methoxyanilino)quinazoline (LJJ-10) compound exhibits anti-metastatic effects in human osteosarcoma U-2 OS cells through targeting insulin-like growth factor-I receptor. Int J Oncol 39: 611-619, 2011.

49. Hour MJ, Yang JS, Chen TL, et al: The synthesized novel fluorinated compound (LJJ-10) induces death receptor- and mitochondria-dependent apoptotic cell death in the human osteogenic sarcoma U-2 OS cells. Eur J Med Chem 46: 2709-2721, 2011.

50. Chiu YJ, Hour MJ, Lu CC, et al: Novel quinazoline HMJ-30 induces U-2 OS human osteogenic sarcoma cell apoptosis through induction of oxidative stress and up-regulation of ATM p53 signaling pathway. J Orthop Res 29: 1448-1456, 2011.

51. Anton N, Gayet P, Benoit JP and Saulnier P: Nano-emulsions and nanocapsules by the PIT method: an investigation on the role of the temperature cycling on the emulsion phase inversion. Int $\mathrm{J}$ Pharm 344: 44-52, 2007.

52. Witt E, Witt F, Trautwein N, et al: Synthesis of lead chalcogenide nanocrystals and study of charge transfer in blends of PbSe nanocrystals and poly(3-hexylthiophene). Phys Chem Chem Phys 14: 11706-11714, 2012

53. Dass A, Guo R, Tracy JB, Balasubramanian R, Douglas AD and Murray RW: Gold nanoparticles with perfluorothiolate ligands. Langmuir 24: 310-315, 2008

54. Lin C, Tsai SC, Tseng MT, et al: AKT serine/threonine protein kinase modulates baicalin-triggered autophagy in human bladder cancer T24 cells. Int J Oncol 42: 993-1000, 2013.

55. Tsai SC, Yang JS, Peng SF, et al: Bufalin increases sensitivity to AKT/mTOR-induced autophagic cell death in SK-HEP-1 human hepatocellular carcinoma cells. Int J Oncol 41: 1431-1442, 2012.

56. Chen HJ, Lin CM, Lee CY, et al: Phenethyl isothiocyanate suppresses EGF-stimulated SAS human oral squamous carcinoma cell invasion by targeting EGF receptor signaling. Int J Oncol 43: 629-637, 2013.

57. Tsai SC, Huang WW, Huang WC, et al: ERK-modulated intrinsic signaling and $\mathrm{G}(2) / \mathrm{M}$ phase arrest contribute to the induction of apoptotic death by allyl isothiocyanate in MDA-MB-468 human breast adenocarcinoma cells. Int J Oncol 41: 2065-2072, 2012.

58. Liao YR, Lu CC, Lai KC, et al: The novel carboxamide analog ITR-284 induces caspase-dependent apoptotic cell death in human hepatocellular and colorectal cancer cells. Mol Med Rep 7: 1539-1544, 2013.

59. Liu CY, Yang JS, Huang SM, et al: Smh-3 induces G(2)/M arrest and apoptosis through calcium mediated endoplasmic reticulum stress and mitochondrial signaling in human hepatocellular carcinoma Hep3B cells. Oncol Rep 29: 751-762, 2013.

60. Lee CY, Chien YS, Chiu TH, et al: Apoptosis triggered by vitexin in U937 human leukemia cells via a mitochondrial signaling pathway. Oncol Rep 28: 1883-1888, 2012.

61. Yang JS, Wu CC, Kuo CL, et al: Solanum lyratum extracts induce extrinsic and intrinsic pathways of apoptosis in WEHI-3 murine leukemia cells and inhibit allograft tumor. Evid Based Complement Alternat Med 2012: 254960, 2012. 
62. Yin HT, Zhang DG, Wu XL, Huang XE and Chen G: In vivo evaluation of curcumin-loaded nanoparticles in a A549 xenograft mice model. Asian Pac J Cancer Prev 14: 409-412, 2013.

63. Jiang L, Luo M, Liu D, et al: BAD overexpression inhibits cell growth and induces apoptosis via mitochondrial-dependent pathway in non-small cell lung cancer. Cancer Cell Int 13: 53, 2013.

64. Balogova L, Maslanakova M, Dzurova L, Miskovsky P and Stroffekova K: Bcl-2 proapoptotic proteins distribution in U-87 MG glioma cells before and after hypericin photodynamic action. Gen Physiol Biophys 32: 179-187, 2013.

65. Plourde MB, Morchid A, Iranezereza L and Berthoux L: The Bcl-2/Bcl-xL inhibitor BH3I-2' affects the dynamics and subcellular localization of sumoylated proteins. Int J Biochem Cell Biol 45: 826-835, 2013

66. Kastelan M, Massari LP and Brajac I: The role of bcl-2 family proteins in psoriasis. Lijec Vjesn 132: 31-33, 2010 (In Croatian).

67. Danial NN: BAD: undertaker by night, candyman by day. Oncogene 27 (Suppl 1): S53-S70, 2008.

68. Levine B, Sinha S and Kroemer G: Bcl-2 family members: dual regulators of apoptosis and autophagy. Autophagy 4: 600-606, 2008.

69. Stauffer SR: Small molecule inhibition of the Bcl-X(L)-BH3 protein-protein interaction: proof-of-concept of an in vivo chemopotentiator ABT-737. Curr Top Med Chem 7: 961-965, 2007.

70. Adams JM and Cory S: The Bcl-2 apoptotic switch in cancer development and therapy. Oncogene 26: 1324-1337, 2007.

71. Kuroda $\mathbf{J}$ and Taniwaki M: Involvement of BH3-only proteins in hematologic malignancies. Crit Rev Oncol Hematol 71: 89-101, 2009.

72. Li Y, Gu J, Liu Y, et al: iNOS participates in apoptosis of spinal cord neurons via p-BAD dephosphorylation following ischemia/ reperfusion (I/R) injury in rat spinal cord. Neurosci Lett 545: $117-122,2013$
73. Hojabrpour P, Waissbluth I, Ghaffari M, Cox ME and Duronio V: CaMKII-gamma mediates phosphorylation of BAD at Ser170 to regulate cytokine-dependent survival and proliferation. Biochem J 442: 139-149, 2012 .

74. Kim W, Yang HJ, Youn H, Yun YJ, Seong KM and Youn B: Myricetin inhibits Akt survival signaling and induces Bad-mediated apoptosis in a low dose ultraviolet (UV)-Birradiated $\mathrm{HaCaT}$ human immortalized keratinocytes. J Radiat Res 51: 285-296, 2010.

75. Yang J: Molecular modeling of human BAD, a pro-apoptotic Bcl-2 family member, integrating glycolysis and apoptosis. Protein Pept Lett 17: 206-220, 2010.

76. Bhat V, Olenick MB, Schuchardt BJ, et al: Heat-induced fibrillation of BclXL apoptotic repressor. Biophys Chem 179: 12-25, 2013.

77. Dorjgochoo T, Xiang YB, Long J, et al: Association of genetic markers in the BCL-2 family of apoptosis-related genes with endometrial cancer risk in a Chinese population. PLoS One 8: e60915, 2013

78. Zhang XH, Chen SY, Tang L, et al: Myricetin induces apoptosis in Hepg 2 cells through Akt/P70s6k/Bad signaling and mitochondrial apoptotic pathway. Anticancer Agents Med Chem: Feb 7, 2013 (Epub ahead of print).

79. Lim GE, Piske M and Johnson JD: 14-3-3 proteins are essential signalling hubs for beta cell survival. Diabetologia 56: 825-837, 2013.

80. Riaz A, Zeller KS and Johansson S: Receptor-specific mechanisms regulate phosphorylation of AKT at Ser473: role of RICTOR in betal integrin-mediated cell survival. PLoS One 7: e32081, 2012. 